\title{
ASSESSMENT OF PAIN AND TRISMUS AND DETERMINING THE DIFFICULTY LEVEL OF TOOTH EXTRACTION WITH MODIFIED PARANT SCALE
}

\author{
Agrawal $M^{1}$, Rahman $Q B^{2}$, Naulakha $D^{3}$, Karki $R^{4}$
}

\section{Affiliation}

1. Lecturer, Department of Oral and Maxillofacial Surgery, Birat Medical College \& Teaching Hospital, Tankisinuwari, Morang, Nepal

2. Professor and Chairman, Department of Oral and Maxillofacial Surgery, Bangabandhu Sheikh Mujib Medical University, Bangladesh, Dhaka

3. Assistant Professsor, Department of Conservative and Endodontics, Nobel Medical College \& Teaching Hospital, Kanchanbari, Morang, Nepal

4. Lecturer, Department of Prosthodontics, Nepal Army Institute of Health Science, Bhandarkhal, Kathmandu, Nepal

\section{ARTICLE INFO}

\section{Article History}

Received : 05 September, 2017

Accepted : 1 November, 2017

Published : 31 December, 2017

(C) Authors retain copyright and grant the journal right of first publication with the work simultaneously licensed under Creative Commons Attribution License CC - BY 4.0 that allows others to share the work with an acknowledgment of the work's authorship and initial publication in this journal.

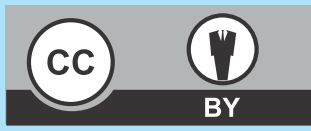

\section{ORA 44}

DOI: http://dx.doi.org/10.3126/bjhs.v2i3.18944

\author{
* Corresponding Author \\ Dr. Manish Agrawal \\ Lecturer \\ Department Of Oral and Maxillofacial Surgery \\ Birat Medical College \& Teaching Hospital \\ Tankisinuwari-02, Morang, Nepal \\ Email:dr.agrawal.manish@gmail.com
}

\section{Citation}

Agrawal M, Rahman QB, Naulakha D, Karki R. Assessment of pain and trismus and determining the difficulty level of tooth extraction with Modified Parant Scale. BJHS 2017;2(3)4:282- 286

\section{ABSTRACT}

\section{Introduction}

Third molar extraction is the most commonly performed procedure by oral and maxillofacial surgeons and most of the extraction leads to minimum per and post operative difficulties if proper preoperative planning is done and if surgical principles are strictly followed.

\section{Objective}

This study evaluated whether pre and post operative pain and trismus were related to difficulty of surgery.

\section{Methodology}

Total number of patients included in this study were 266 (male 135 and female 131), age range from 18 to 34 years. Preoperative diagnosis was made by clinical examination and radiographs. Clinical examination was done to determine pain, swelling and mucosal coverage of tooth whereas OPG and RVG were taken to assess the angulations, level of tooth impaction and bony coverage of tooth. Standardized technique was used for tooth extraction; buccal guttering, adequate elevation, reflection of mucoperiosteal flap, crown sectioning and ostectomy. Evaluation of pain and trismus was done preoperatively, on first and third post operative day. SPSS version 16 was used to analyse the data. Chi square $\left(\mathrm{x}^{2}\right)$ test and unpaired ' $t$ ' test were done. Modified Parant Scale was used to evaluate the difficulty of tooth extraction; Group I: forceps extraction; Group II: ostectomy; Group III: ostectomy and crown sectioning; Group IV: difficult extraction.

\section{Results}

When both preoperative and postoperative results were compared after data analysis, pain was significantly reduced and significant inter incisal opening was achieved, in both the groups $P>0.05$. The results were statistically not significant.

\section{Conclusion}

Postoperative pain and trismus was minimum in (Group I) then in (Group II to IV). The incidence of postoperative pain and trismus among all the groups were more or less similar. Hence, no significant difference was found.

\section{KEYWORDS}

Pain measurement, tooth extraction, trismus 


\section{INTRODUCTION}

Third molar extraction has been and still is the most frequent operation performed by oral and maxillofacial surgeons both in private practice and in hospital settings. ${ }^{1}$ Third molar generally erupt between the age of 18 to 24 years though there is wide variation in eruption dates. ${ }^{2}$ The average age for mandibular $3^{\text {rd }}$ molar eruption, in male is approximately 3 to 6 months ahead of females. ${ }^{3}$ Some authors reported that the incidence of mandibular $3^{\text {rd }}$ molar impaction is greater in females. ${ }^{4,5}$

The most commonly impacted tooth in oral cavity is mandibular $3^{\text {rd }}$ molar and of all impactions $98 \%$ comprises of mandibular $3^{\text {rd }}$ molars. ${ }^{6,7}$ The frequency of $3^{\text {rd }}$ molar impaction ranges from $18 \%$ to $70 \%$ which varies among different populations. The eruption of tooth depends upon the racial variation, facial growth, arch length and tooth size. ${ }^{8}$ The prevalence of $3^{\text {rd }}$ molar impaction ranges from 27-68.6\% whereas few studies from the Gulf region have revealed the prevalence to be $32-40.5 \%$. Some author showed the prevalence of $3^{\text {rd }}$ molar impaction for, one $3^{\text {rd }}$ molar $=3-4 \%$, two $3^{\text {rd }}$ molar $=8-11 \%$, three $3^{\text {rd }}$ molars $=9$ $12 \%$ and four $3^{\text {rd }}$ molars $=73-77 \%$. $^{10,11}$

Third molar extraction is a clean contaminated surgery and the chances of postoperative infection is not more than $5 \%{ }^{12}$ The risk of wound infection after surgical removal of $3^{\text {rd }}$ molar is precisely low between 1 and $6 \% .^{13}$ Different classification systems has been introduced to assess the difficulty level of tooth extraction but they are of minimal clinical use. ${ }^{14}$ Classification systems are based on the preoperative evaluation of OPG xrays whereas some authors have used numerical and clinical variables. ${ }^{14,15}$

Postoperative pain and trismus is always associated with age of the patient. The major risk factor for developing postoperative complications are tooth angulation, position and the age of the patient, there are $10 \%$ chances for developing postoperative complications in 20 year old patients where as more than $30 \%$ chances for 40 year old patients. $^{16}$

Postoperative pain, swelling and trismus are always expected during the healing phase after surgical and non surgical removal of $3^{\text {rd }}$ molars, they are transient and are not considered as complications. ${ }^{17}$ Careful surgical technique and scrupulous perioperative care can minimize the frequency of complications and limit their severity. A thorough understanding of the complications associated with this procedure will enable the surgeon to counsel high risk patients, manage the complications appropriately, be cognizant of less common sequelae and the most effective method of management. ${ }^{18}$ The postoperative pain, swelling and trismus is always associated with reflection of mucoperisoteal flap where as a smaller incision and minimal reflection will result in minimal pain, swelling and trismus. ${ }^{19}$

Pain is an unpleasant sensory and emotional experience associated with actual or potential tissue damage or described in terms of such damage. ${ }^{20}$ Pain is always associated with tooth extraction, suturing, type of impaction and operative time. $^{21}$ Trismus is a state or condition where mouth opening is transient and it occurs due to tonic contraction of muscles of mastication. ${ }^{22}$ Trismus is directly proportionate to surgical tooth extraction, the duration of surgery, ostectomy and crown sectioning. ${ }^{21}$

This is a single operator study whereas all past studies were evaluated by different operators. In the work reported here, we evaluated pain and trismus in 266 patients who had undergone removal of mandibular $3^{\text {rd }}$ molars and evaluated the difficulty level of surgery on both responses.

\section{METHODOLOGY}

This cross sectional study was performed in the Department of Oral and Maxillofacial Surgery, Faculty of Dentistry, Biratnagar Hospital PVT LTD and Birat Medical College and Teaching Hospital, Biratnagar, Nepal from 2014 to June 2017. Informed written consent was taken from the patient and their legal guardians. The patients were informed clearly about the treatment procedure, the results, advantages, disadvantages and possible postoperative complications.

Total of 266 patients, 135 male and 131 female with age ranging from 18 to 34 years were included in this study. Inclusion criteria were as follows; Asymptomatic tooth indicated for extraction; $3^{\text {rd }}$ molar causing damage to the adjacent tooth, serial extraction, orthodontic purpose, orthognathic surgery, Age: 18 years -38 years, impacted tooth and patients showing cooperation with the study. Orthopantomogram was taken as a standard and was advised to all the patients. Preoeprative radiographs were taken to assess the difficulty level of surgery preoperatively according to Modified Parant Scale.

Difficulty of tooth extraction was evaluated on MPS; Group I: forceps extraction; Group II: ostectomy; Group III: ostectomy and crown sectioning; Group IV: difficult extraction. The duration of surgery from incision to last suture was recorded after every tooth extraction. ${ }^{19,23,24}$

Tooth extraction was performed under local anaesthesia. Before tooth extraction each and every patients were in pain and infection free state. $0.12 \%$ chlorhexidine mouth wash was given to each patient immediately before tooth extraction. Standardized technique was used for tooth extraction; buccal guttering, adequate elevation and reflection of mucoperiosteal flap, crown sectioning and ostectomy. Patients were asked to strictly follow the postoperative instructions given by the surgeon after tooth.

Patients were asked to come on $1^{\text {st }}$ and $3^{\text {rd }}$ POD for assessment of pain and to measure inter incisal distance. Visual Analogue Scale (VAS) was used to assess the pain intensity. Digital vernier calliper or measuring scale according to avaibility were used to measure inter incisal distance from incisal edge of the upper and lower right central incisors. Photographs were also taken for records. Results were arranged in tables. SPSS version 16 was used for data analysis. The evaluation was done by unpaired't' test. The result was considered significant when $p$ value was $<0.05$. 


\section{RESULTS}

Out of 266 patients, 135 (50.75\%) were male and 131 (49.25\%) were female (Table 1). Mesioangular and Vertical were the common impaction of all, $51.88 \%$ and $24.44 \%$ respectively. Teeth in position A and position B were $60.53 \%$ and $36.47 \%$ respectively whereas teeth without Mucosal and Bony Coverage were $60.53 \%$ and $66.17 \%$ respectively. Patients were pain free before tooth extraction $\mathrm{P}$ value was 0.648 and 0.508 on $1^{\text {st }}$ and $3^{\text {rd }}$ POD respectively for intensity of pain (Table 1). p value for inter incisal distance was 0.691 , 0.291 and 0.507 preoperatively, $1^{\text {st }}$ and $3^{\text {rd }}$ POD respectively
(Table II). Mean inter incisal distance and duration of surgery in each parant groups are listed in Table (I, II, III and IV).

Inter incisal distance before tooth extraction was almost same in all four Parant groups. On $1^{\text {st }} P O D$ inter incisal distance was more in group I then in group II, III and IV, on $3^{\text {rd }}$ POD also it was greater in group I then in group II, III and IV. Interincisal distance in group I did not show any significant change over time but in groups II, III and IV it varied significantly with time. Time taken for tooth extraction was less in group I patients than in the other group patients and significantly higher in group IV when compared to other groups. Results were statistically not significant.

Table 1 : Age and sex distribution of the patient $(n=266)$

\begin{tabular}{|c|c|c|c|c|c|c|c|c|c|c|}
\hline \multirow[t]{2}{*}{$\begin{array}{l}\text { Age } \\
\text { (Years) }\end{array}$} & \multicolumn{2}{|c|}{ Group I } & \multicolumn{2}{|c|}{ Group II } & \multicolumn{2}{|c|}{ Group III } & \multicolumn{2}{|c|}{ Group IV } & \multicolumn{2}{|c|}{$\begin{array}{l}\text { Total Number of } \\
\text { Patients ( } \mathrm{n})\end{array}$} \\
\hline & Male & Female & Male & Female & Male & Female & Male & Female & Male & Female \\
\hline $18-26$ & $\begin{array}{c}25 \\
9.40 \%\end{array}$ & $\begin{array}{c}16 \\
6.02 \%\end{array}$ & $\begin{array}{c}32 \\
12.03 \%\end{array}$ & $\begin{array}{c}38 \\
14.29 \%\end{array}$ & $\begin{array}{c}12 \\
4.51 \%\end{array}$ & $\begin{array}{c}17 \\
6.39 \%\end{array}$ & $\begin{array}{c}5 \\
1.88 \%\end{array}$ & $\begin{array}{c}2 \\
0.75 \%\end{array}$ & $\begin{array}{c}74 \\
27.82 \%\end{array}$ & $\begin{array}{c}73 \\
27.44 \%\end{array}$ \\
\hline $27-30$ & $\begin{array}{c}10 \\
3.76 \%\end{array}$ & $\begin{array}{c}18 \\
6.77 \%\end{array}$ & $\begin{array}{c}12 \\
4.51 \%\end{array}$ & $\begin{array}{c}10 \\
3.76 \%\end{array}$ & $\begin{array}{c}11 \\
4.14 \%\end{array}$ & $\begin{array}{c}8 \\
3.00 \%\end{array}$ & $\begin{array}{c}3 \\
1.13 \%\end{array}$ & $\begin{array}{c}2 \\
0.75 \%\end{array}$ & $\begin{array}{c}36 \\
13.53 \%\end{array}$ & $\begin{array}{c}38 \\
14.29 \%\end{array}$ \\
\hline $31-34$ & $\begin{array}{c}5 \\
1.88 \%\end{array}$ & $\begin{array}{c}4 \\
1.50 \%\end{array}$ & $\begin{array}{c}10 \\
3.76 \%\end{array}$ & $\begin{array}{c}14 \\
5.26 \%\end{array}$ & $\begin{array}{c}10 \\
3.76 \%\end{array}$ & $\begin{array}{c}2 \\
0.75 \%\end{array}$ & 0 & 0 & $\begin{array}{c}25 \\
9.40 \%\end{array}$ & $\begin{array}{c}20 \\
7.52 \%\end{array}$ \\
\hline Total & $\begin{array}{c}40 \\
15.04 \%\end{array}$ & $\begin{array}{c}38 \\
14.29 \%\end{array}$ & $\begin{array}{c}54 \\
20.30 \%\end{array}$ & $\begin{array}{c}62 \\
23.31 \%\end{array}$ & $\begin{array}{c}33 \\
12.41 \%\end{array}$ & $\begin{array}{c}27 \\
10.15 \%\end{array}$ & $\begin{array}{c}8 \\
3.01 \%\end{array}$ & $\begin{array}{c}4 \\
1.50 \%\end{array}$ & $\begin{array}{c}135 \\
50.75 \%\end{array}$ & $\begin{array}{c}131 \\
49.25 \%\end{array}$ \\
\hline
\end{tabular}

Table 2: Number of patients and difficulty level of surgery $(n=266)$

\begin{tabular}{|c|c|c|c|c|}
\hline & \multicolumn{4}{|c|}{ PARANT GROUPS } \\
\hline & 1 & II & III & IV \\
\hline \multicolumn{5}{|l|}{ Total Number of Patients n (\%) } \\
\hline $\mathrm{n}$ & $78 / 266$ & $116 / 266$ & $60 / 266$ & $12 / 266$ \\
\hline (\%) & 29.32 & 43.61 & 22.56 & 4.51 \\
\hline $\begin{array}{c}\text { Difficulty level of surgery(min) } \\
\text { Mean } \pm S D\end{array}$ & $10.40 \pm 2.50$ & $15.30 \pm 2.00$ & $18.00 \pm 4.45$ & $24.50 \pm 5.00$ \\
\hline
\end{tabular}

Table 2: Difference in Intensity of Pain (VAS) with Period of Evaluation $(n=266)$

\begin{tabular}{|c|c|c|c|c|c|}
\hline \multirow{2}{*}{ Pain } & \multicolumn{4}{|c|}{ PARANT GROUPS } & P value \\
\hline Period of Evaluation & Mean \pm SD & Mean \pm SD & Mean \pm SD & Mean \pm SD & \\
\hline Preoperative & $0.0+0.0$ & $0.0+0.0$ & $0.0+0.0$ & $0.0+0.0$ & - \\
\hline $1^{\text {st }}$ POD & $3.39 \pm 2.5$ & $3.61 \pm 2.45$ & $3.68 \pm 2.45$ & $3.72 \pm 2.40$ & $0.648^{\text {ns }}$ \\
\hline $3^{\text {rd }}$ POD & $1.18 \pm 1.42$ & $1.36 \pm 1.43$ & $1.42 \pm 1.56$ & $1.51 \pm 1.62$ & $0.508^{\text {ns }}$ \\
\hline
\end{tabular}

ns $=$ Not Significant. Significant cutoff value $<0.05$

Table 3 : Difference in Inter Incisal Distance with Period of Evaluation ( $n=266$ )

\begin{tabular}{|c|c|c|c|c|c|}
\hline \multirow{2}{*}{ Inter Incisal Distance } & \multicolumn{4}{|c|}{ PARANT GROUPS } & \multirow[t]{2}{*}{$P$ value } \\
\hline & 1 & II & III & IV & \\
\hline Period of Evaluation & Mean \pm SD & Mean \pm SD & Mean \pm SD & Mean+SD & \\
\hline Preoperative & $52.56 \pm 10.37$ & $51.9 \pm 6.81$ & $51.24 \pm 3.25$ & $50.58 \pm 0.31$ & $0.691^{\mathrm{ns}}$ \\
\hline $1^{\text {st }}$ POD & $43.78 \pm 15.25$ & $40.78 \pm 9.87$ & $37.64 \pm 10.5$ & $41.72 \pm 10.3$ & $0.291^{\text {ns }}$ \\
\hline $3^{\text {rd }}$ POD & $52.82 \pm 10.24$ & $49.91 \pm 11.52$ & $48.56 \pm 7.19$ & $51.91 \pm 6.56$ & $0.507^{\mathrm{ns}}$ \\
\hline
\end{tabular}

ns $=$ Not Significant. Significant cutoff value $<0.05$ 


\section{DISCUSSION}

In most of the individuals $3^{\text {rd }}$ molars are congenitally absent and if present due to tooth size and smaller arch length it may become impacted. Approximately $98 \%$ of all impacted teeth accounts for mandibular $3^{\text {rd }}$ molars. ${ }^{25}$

Postoperative morbidity is always associated with aggressiveness of the surgeon and surgery, duration of tooth extraction, bone removal and crown sectioning. Understanding of preoperative surgical difficulty is not only important for general practitioners to be able to refer patient to specialist but it also helps to inform patients about the possible intra operative and post operative complications and it also increases patients level of satisfaction with the treatment received. It has been obvious from many studies that pre operative, intra operative \& post operative indicators exist which contribute to evaluate post operative complications. ${ }^{26}$ Preoperative radiographs have great importance in assessment of surgical difficulty given as indicated by many studies. ${ }^{27}$

Inter incisal distance should always be measured by the same surgeon to avoid observer bias. Patients had no wound infection and other related complications after tooth extraction (simple or surgical) according to this study. Hence, postoperative pain can be reduced and maximum mouth opening can be achieved with meticulous tissue manipulation, administration of analgesics, proper wound care by patient and regular follow-up.

The evaluation of pain is always subjective which is assessed using visual analog scale that varies with individuals. ${ }^{28}$ The assessment of trismus is objective which is measured by determining inter inicsal distance using digital vernier caliper. Postoperative morbidity like pain and trismus are related to difficulty of surgery. Thus, prostaglandins and other inflammatory mediators are released from membrane phospholipids as a result of tooth extraction (simple or surgical). ${ }^{29}$

Various indexes have been proposed and are used by clinicians to classify difficulty of impacted $3^{\text {rd }}$ molar removal. ${ }^{15}$ There are three imaginary lines in the form of Both Winter's and Pell and Gregory classification are unreliable and are used less in clinical practice though these methods are taught to most undergraduate students. ${ }^{15,19,21}$ MPS is considered to be relatively more reliable according to most studies but it is also less reliable for clinical and radiological parameters discussed above. ${ }^{23}$

Pain is a useful clinical model for evaluation of analgesics after tooth extraction. Analgesics after tooth extraction always enhances the patients comfort, decrease the pain and stress. ${ }^{28}$

Some author reported that the most common impaction were vertical followed by mesioangular, $42.92 \%$ and $36.94 \%$ respectively and few reported that mesioangular over vertical, $37.5 \%$ and $35 \%$ respectively whereas our study revealed mesioangular $51.88 \%$ were most common then vertical $24.44 \%$ impaction. ${ }^{30,31}$ Some authors reported that the teeth with total mucosal and partial bony coverage were $60.5 \%$ and $70 \%$ respectively. ${ }^{31}$ According to our study most of the teeth were without mucosal and bony coverage, $60.53 \%$ and $66.17 \%$ respectively.

Surgical difficulty was found to be more with those teeth which were in position $C$ rather than position $A$ and $B$.
Gulsun et al reported that the most common position of teeth were in position $B$ and $A, 52.90 \%$ and $31.44 \%$ respectively whereas our study showed that the most common position of teeth were, position A and B, $60.53 \%$ and $36.47 \%$ respectively. ${ }^{30}$

Eeden et al reported that $p$ value for the intensity of pain on $1^{\text {st }}$ and $3^{\text {rd }}$ POD was 0.882 and 0.107 respectively whereas our study revealed that mean + SD for the Intensity of Pain on $1^{\text {st }}$ and $3^{\text {rd }}$ POD was $3.6 \pm 2.45$ and $1.37 \pm 1.51$ respectively, hence $p>0.05$, statistically not significant. ${ }^{21}$

Poeschl et al revealed that overall occurrence of difference in mouth opening (inter incisal distance) after surgery ranges from $3.4 \%$ to $4.4 \%$; mean $3.98 \%$ whereas our study showed mean+SD for inter incisal distance preoperatively, $1^{\text {st }}$ and $3^{\text {rd }}$ POD was $51.57 \pm 5.19,40.98 \pm 11.48$ and $50.8 \pm 8.88$ respectively, hence $p>0.05$, statistically not significant between all groups. ${ }^{32}$

Interincisal distance between Parant groups II, III, and IV postoperatively was more or less same. To evaluate postoperative trismus these three Parant group represents same level of difficulty, hence these three groups has been denominated as surgical extraction whereas interincisal distance in Parant group I was satisfactory, hence this group has been denominated as simple or non surgical extraction.

Whenever the patients are asked to open the mouth to measure inter incisal distance, the measurement differ in every follow up. Hence, normal distance may vary considerably in same patient. The values obtained by various clinicians is directly proportional to the measuring device used: a vernier caliper may hold the mouth open wide to some extent whereas a measuring scale cannot hold the mouth open wide. The study showed that there was no significant difference between the results. We think that this study can be a base for further studies to examine the differences in postoperative morbidity (pain and trismus) after surgical or non surgical extractions. However, further study could be done with larger sample size and greater logistic support.

\section{CONCLUSION}

Pain and trismus both are directly proportional to aggressiveness of the surgeon and difficulty of surgery. However, this study has tried to evaluate the results objectively by comparing pre and post operative photographs and patient clinician interaction. Postoperative pain and trismus was minimum after simple or non surgical tooth extraction cases (Group I) when compared to surgical extraction (Group II to IV). Regardless of extraction type, intensity of pain decreases and inter incisal distance increases between $1^{\text {st }}$ and $3^{\text {rd }}$ post operative day. According to our study the incidence of postoperative pain and trismus among all the groups were more or less similar. Hence, no significant differences among the groups in the incidence of pain and trismus was found.

\section{RECOMMENDATION}

Further studies with more advanced technology and modern instruments can be done to obtain more accurate results. 


\section{LIMITATION OF THE STUDY}

Pain is a subjective response which varies with individuals so more advanced technology to record or measure pain then Modified Parant Scale and VAS would give the accurate results.

Trismus is objectively measured. Inter incisal distance varies with age, sex, race, size of cranial base and mandible along with individuals body height and weight. Newer instruments like Hu-Friedy Boley Gauge with locking system can be used. More accuracy can be obtained if mouth opening is measured 3 times within 15 minutes with the patient relaxed 10 minutes prior to measurement.

\section{REFERENCES}

1. Fuster Torres MA, Gargallo Albiol J, Berini Aytés L, Gay Escoda C. Evaluation of the indication for surgical extraction of third molars according to the oral surgeon and the primary care dentist. Experience in the Master of Oral Surgery and Implantology at Barcelona University Dental School. Med Oral Patol Oral Cir Bucal, 2008; 13(8): E499-E504.

2. Vilela EM, Vitoi PA. Study of position and eruption of lower third molars in adolescents. Rev Sul-Bras Odontol, 2011; 8(4): 390-397.

3. Hattab FN, Alhaija ES. Radiographic evaluation of mandibular third molar eruption space. Oral Surg Oral Med Oral Pathol Oral Radiol Endod. 1999 Sep; 88 (3):285-91.

4. Kruger E, Thomson WM, Konthasinghe P. Third molar outcomes from age 18 to 26: findings from a population-based New Zealand longitudinal study. Oral Surg Oral Med Oral Pathol Oral Radiol Endod. 2001 Aug;92 (2):150-5.

5. Yuasa $H$, Sugiura $M$. Cinical postoperative findings after removal of impacted mandibular third molars: prediction of postoperative facial swelling and pain based on preoperative variables. Br J Oral Maxillofac Surg. 2004 Jun;42 (3):209-14.

6. Othman R, Tin-Oo MM. Impacted mandibular third molars among patients attending Hospital Universiti Sains Malaysia. Arch Orofac Sci, 2009; 4(1): 7-12.

7. Alling CC, Helfrick JF,Alling RD. Impacted teeth. Philadelphia: WB Saunders.1993.

8. MarwaHatem, Imambugaighis, Elsanousi M. Taher. Pattern of third molar impaction in Libyan population: A retrospective radiographic study. sjdr. 2015.

9. Samira M Al-Anqudi, Salim Al-Sudairy, Ahmed Al-Hosni, Abdullah AlManiri. Prevalence and pattern of Third Molar Impaction. A retrospective study of radiographs in Oman. Sultan Qaboos Univ Med J. 2014 Aug;14 (3):e388-e392.

10. Hugoson A, Kugelberg CF. The prevalence of third molars in a Swedish population. An epidemiological study. Community Dent Health 1988; 5:121-38.

11. Hattab FN, Rawashdeh MA, Fahmy MS. Impaction status of third molars in Jordanian students. Oral Surg Oral Med Oral Pathol Oral Radiol Endod 1995; 79:24-9.

12. Piecuch JF, Arzadon J, Lieblich SE. 'Prophylactic antibiotics for third molar surgery: A supportive opinion', J Oral Maxillofac Surg, 1995; vol. 53, pp. 53-60.

13. Loukota RA.'The effect of pre-operative perioral skin preparation with aqueous povidone-iodine on the incidence of infection after third molar removal', Br J Oral Maxillofac Surg, 1991; vol. 29, pp. 336-7.

14. Almendros-Marqués N, Berini-Aytés L, GayEscoda C. Influence of lower third molar position on the incidence of preoperative complications. Oral Surg Oral Med Oral Pathol Oral Radiol Endod, 2006; 102(6): 725-732.

15. Yuasa $\mathrm{H}$, Kawai $\mathrm{T}$, Sugiura M. Classification of surgical difficulty in extracting impacted third molars. Br J Oral Maxillofac Surg, 2002; 40(1): 26-31.

16. Renton T, Smeeton N, McGurk M. 'Factors predictive of difficulty of mandibular third molar surgery'. Br Dent J, 2001; vol. 190, pp. 607-610.

\section{ACKNOWLEDGEMENT}

We would like to acknowledge each and every member of Department of Oral and Maxillofacial Surgery, Birat Medical college \& Teaching Hospital, Biratnagar, Morang, Nepal and my colleagues from other Department (ENT), for their continuous and immense support. Their patience, motivation and logical way of thinking helped me during writing of this research article.

\section{CONFLICT OF INTEREST}

We declare no conflict of interest.

17. Bouloux GF, Steed MB. 'Complications of third molar surgery'. Oral Maxillofac Surg Clin North Am, 2007; vol.19, pp. 117-128.

18. Srinivas M Susarla, Bart F Blaeser, Daniel Magalnick. Third molar surgery and associated complications. Oral Maxillofacial Surg Clin N Am, 2003; vol. 15, pp. 177-186.

19. Garcia AG, Sampedro FG, Rey JG, Vila PG, Martin MS. 'Pell-Gregory classification is unreliable as a predictor of difficulty in extracting impacted lower third molars'. Br J Oral Maxillofac Surg, 2000; vol. 38, pp. 585-587.

20. ICSI (eds.). 'Algorithms and Annotations, Scope and Target Population'. In: Health Care Guideline: Assessment and Management of Acute pain, $6^{\text {th }}$ ed, p. 4. . 2008.

21. Eeden van SP, Butow K. 'Post-operative sequelae of lower third molar removal: a literature review and pilot study on the effect of Covomycin D'. SADJ, 2006; vol. 61, pp. 154-159.

22. Venes D, Biderman A, Adler, E (ed.) . 'Taber's cyclopedic medical dictionary'. $20^{\text {th }}$ ed, Jaypee Brothers Medical Publishers (P) Ltd, New Delhi, 2006; vol. 2, p. 2120.

23. Diniz-Freitas M, Lago-Méndez L, GudeSampedro F, Somoza-Martin JM, GándaraRey JM, García-García A. Pederson scale fails to predict how difficult it will be to extract lower third molars. $\mathrm{Br} J$ Oral Maxillofac Surg, 2007; 45(1): 23-26.

24. Barreiro-Torres J, Diniz-Freitas M, LagoMéndez L, Gude-Sampedro F, GándaraRey JM, García-García A. Evaluation of the surgical difficulty in lower third molar extraction. Med Oral Patol Oral Cir Bucal, 2010; 15(6): e869-e874.

25. Benediktsdóttir IS, Wenzel A, Petersen JK, Hintze H. Mandibular third molar removal: risk indicators for extended time, post operative pain and complications. Oral Surg Oral Med Oral Pathol Oral Radiol Endod, 2004; 97(4): 438-446.

26. Koong B, Pharoah MJ, Bulsara M, Tennant M. Methods of determining the relationship of the mandibular canal and third molars: a survey of Australian oral and maxillofacial surgeons. Aus Dent J, 2006; 51(1): 64-68.

27. Garcia AG, Sampedro FG, Rey JG, Torreira MG. 'Trismus and pain after removal of impacted third molars'. J Oral Maxillofac Surg, 1997; vol. 55, pp. 1223-1226.

28. Smith WI, Mamett LJ. Prostaglandin endoperoxide synthase: Structure and catalysis. Biochim Biophys Acta 1991; 1083:1.

29. Bui $\mathrm{CH}$, Seldin EB, Dodson TB. 'Types, frequencies, and risk factors for complictions after third molar extraction'. J Oral Maxillofac Surg, 2003; vol. 61, pp. 1379-89.

30. Gulsun Y, Hanife A, TurkerB, Dilek KM, Birkan TO. 'Is it different in Turkish population? Evaluation of impacted third molars'. SU Dishek Fak Derg, 2009; vol. 18, pp. 55-62.

31. Almendros MN, Alaejos AE, Quinteros BM, Berin AL, Gay EC. 'Factors influencing the prophylactic removal of asymptomatic impacted lower third molars'. Int J Oral Maxillofac Surg, 2008; vol. 37, pp. 29-35.

32. Poeschl, PW, Eckel, D, Poeschl, E. 'Postoperative prophylactic antibiotic treatment in third molar surgery - a necessity?'. J Oral Maxillofac Surg, 2004; vol. 62, pp. 3-8. 